\title{
Technical Specialized Knowledge and Founder Leadership at Initial Public Offering
}

\author{
Jon Eckhardt (University of Wisconsin-Madison) \\ Marc Junkunc (Washington and Lee University) \\ Mingxiang Li (Florida Atlantic University)
}

KEYWORDS: Entrepreneurship, Management, IPOs, Venture Capital, Startups.

\section{Technical Specialized Knowledge and Founder Leadership at Initial Public Offering}

This study examines factors that influence the likelihood that founders hold executive level positions in firms at the point of Initial Public Offering (IPO). Our model is conceptually more comprehensive than existing work, as we develop theory that examines founder involvement across executive positions beyond the often-studied chief executive officer (CEO). We examine our hypotheses using a database that contains virtually all IPOs spanning an 11-year period when the IPO market was active. Our empirical evidence indicates that a surprising number of founders hold leadership positions in firms at IPO. The research shows that factors that predict founder succession differ across executive positions.

\section{INTRODUCTION}

Prior research indicates that differences often exist between the human capital necessary to draw realistic inferences about the existence of an entrepreneurial opportunity to form a firm and the human capital that is necessary to manage a firm once it has been formed (Scott Shane 2000; Eckhardt and Shane 2003; G. S. Becker 1994). Scholars have argued that this separation in human capital between knowledge that enables people to discover specific opportunities and knowledge that is required to manage firms formed to exploit them is a major influence in the separation between firm ownership and professional management as firms evolve (Chandler 1977; Wasserman 2003).

A growing literature has examined founder succession as a special case of managerial succession, in part because this is a setting where the human capital needs of firms often outgrow the human capital provided by the founding team. Therefore, we often observe the situation when founding team members are replaced by professional managers. While human capital theory suggests that the fit between the skills of the top management team and the needs of the firm are crucial for better performance, the specifics about when founding team members are replaced are not well explored, and hence an opportunity to advance theory remains.

We theorize that understanding the knowledge requirements of firms helps to explain when founders will hold specific executive positions in firms at the time they seek equity investment from outsiders via an Initial Public Offering (IPO). Our mechanism is driven by two fundamentally different knowledge attributes of firms that at times place different pressures on members of the founding team depending on their role in at the firm. The first, technical specialized knowledge (TSK), captures the type of knowledge utilized by a firm (Junkunc and Eckhardt 2009) while the second, R\&D expenditures, measures the search for new knowledge of any form (Klevorick et al. 1995).

Our project advances the literature by integrating into our model and analysis the fact that firms are often founded by teams of individuals, and, hence, founder succession often occurs across several quite different executive positions beyond the often-studied founderCEO transition. In our analysis, we studied founder transition in three positions across the executive team: the CEO, the chief financial officer (CFO) and the chief technology officer (CTO). Additionally, we are able to control for contextual factors that are beyond the scope of single industry work that is the context for much of the research on founder transition. Our data crosses all industries and virtually all IPOs in a 11-year period. 
Unlike prior research that samples from a single industry, our multiple-industry study is likely to have greater external validity. To foreshadow our inferences, our empirical analysis indicates that the likelihood of founder CEOs turnover was determined by the knowledge embedded within the top management team and the company. Specifically, when there is more technical specialized knowledge embedded within the top management team, founder CEOs are more likely to be retained.

We also examined the paradox of success hypothesis that has been investigated by Noam Wasserman (Wasserman 2003) in the software industry. To the extent that raising additional rounds of capital is a success metric as treated in Wasserman's analysis (2003), our study supports the paradox of success. We find that firms that have successfully completed more rounds of financing are less likely to have founders in executive positions. However, we do not find support for Wasserman's paradox of success when looking at more widely used measures of success for startup companies, such as sales growth (Graham 2010) that were not used in his original work.

Using a historical sample consisting of firms that went public between 1992 and 2002, we investigate how firmlevel factors such as sales growth, financing events, and human capital influenced founder-executive turnover or retention in these newly public firms. In particular, in contrast to commonly held beliefs, we first find clear evidence that executive positions are more likely to be held by founders in ventures with high levels of technical specialized knowledge. We further demonstrated that $R \& D$ plays a different role in determining the retention of founder-CEOs and founderCTOs. This paper is organized into three sections. We first discuss our theory and hypotheses. Second, we detail our data sources, measures, and analytical techniques. Finally, we conclude by illustrating our empirical findings, contributions and limitations.

\section{THEORY AND HYPOTHESES}

Firms are heterogeneous in their use of knowledge. This means that firms differ in the types of knowledge that they use and in the extent to which they search for new knowledge. For example, Starbucks Corp (SBUX) is a firm that went public in 1992. At IPO the firm reported that it conducted no R\&D and none of the members of the founding team held a PhD degree. In contrast, Watson Pharmaceuticals (WPI) is a firm that was formed to develop and sell biologic pharmaceutical products. Five members of the management team held a PhD degree at the time the firm went public in 1993 and regulatory filings indicate that the firm was applying science to develop advanced proprietary products.

We conceptualize the relationship between knowledge and a firm's activities along two dimensions. The first dimension is the extent to which scientific knowledge is important to the business. The second dimension is the extent to which the firm is engaged in the search for new knowledge. We theorize that the way in which knowledge relates to firms' activities is helpful in understanding whether founders will continue to hold specific executive positions at the time a firm sells equity in an IPO. Firms that have reached a stage where they are listed on public markets are fundamentally different from seed stage organizations that were staffed by the founding team. Listed firms have more employees, formalized business processes, and must respond to greater regulatory requirements than seedstage companies. This means that as firms mature, founders in leadership roles are often replaced with more experienced managers who are skilled at managing complex enterprises (Wasserman 2003).

In this paper, we focus on three positions: the chief executive officer (CEO), the chief financial officer (CFO), and the chief technical officer (CTO). We focus on these three positions due to concerns about construct validity regarding other executive positions where the responsibilities of positions with similar titles cover different activities. In addition, not all firms have the CTO position. We address this issue empirically below.

We theorize that the management for the search for new knowledge is in most cases a generic managerial skill. Hence, founders are likely to be replaced in most executive positions even in those firms that engage in extensive R\&D. However, we theorize that the application of specific bodies of scientific knowledge to specific business opportunities and problems is not a generic business skill. Hence, as we explain in more detail below, founders are more likely to hold specific executive positions in firms that apply science to business.

\section{Application of Scientific Knowledge to Commercial Activities}

The application of science to commercial activities 
occurs through the actions and knowledge of specific people. Junkunc \& Eckhardt (2009) describe the technical specialized knowledge (TSK) of an individual as the scarce technical skills combined with the accumulated contextual knowledge derived from both life experience and education. TSK explicitly includes business and other work experiences, as well as related intellectual endeavors, and the prior pursuit of specific opportunities. The core idea of TSK is that direct experience with a specific body of knowledge and the accompanying technologies can be a prerequisite to achieving a complete understanding of a particular domain. For example, the productivity of specialists at particular tasks depends on how much knowledge they have (G. Becker and Murphy 1992).

For our theory, we assume that not all individuals have the same education and life experiences, hence TSK is not evenly distributed amongst individuals nor organizations (Venkataraman 1997). This definition of TSK is distinct from the concept of tacit knowledge since the focus here is squarely on the differences in knowledge stocks that influence an individual's ability to differently understand specific complex bodies of information (Lindsay and Norman 1977; Michael 2012), instead of on the properties of the knowledge itself which may simply impede transfer (Winter 1990).

An uneven distribution of TSK amongst individuals fosters information asymmetries and causal ambiguity. However, asymmetries arising from TSK are unique in the sense that the mere disclosure of complex information will not eliminate them unless the party receiving the information possesses the requisite TSK to comprehend the complex information (Junkunc and Eckhardt 2009). For example, Junkunc \& Eckhardt (2009) note that while mathematical models in the social sciences are easily codifiable, and hence easily disclosed, substantial investment in specialized knowledge is necessary before certain other individuals could readily understand such models and apply them. In settings where TSK is important, the transfer of complex information between individuals becomes difficult, and hence asymmetries that arise as a result of TSK are likely to persist. We argue that TSK is a type of valuable and rare resource that can bring causal ambiguity. This is a very important condition for firms to achieve sustained competitive advantage (Barney 1991).

Importantly for our work here, firms are not equally dependent upon the use of TSK. For example, Cohen, Nelson \& Walsh (Cohen, Nelson, and Walsh 2002) found that advances in specific academic disciplines (e.g. physics) are relatively more important to firms pursuing some opportunities (e.g. those related to semiconductors or computers) than to others (e.g. machine tools or food, in the case of physics). One indication of this is the use of scientists and engineers in the economy. Data from the National Science Foundation (2009) indicates that scientists and engineers comprised approximately 9.3 percent of the workforce $(8,470$ employees) in industrial inorganic chemicals while only 0.2 percent of the workforce ( 450 employees) in lumber and construction material.

In consideration of a typical lifecycle for firms, the reliance on key insiders for commercial success may be expected to dissipate over time (Churchill and Lewis 1983). Normally at the early stages of venture formation, founders facilitate the recognition of an opportunity, as well as the personal, idiosyncratic development of the concept while working with early investors to realize the opportunity, which is crucial to the venture's early success (S. Shane and Cable 2002; Kroll, Walters, and Le 2007). As the venture begins to develop into a more formalized organization, the importance of those particular individuals may decline as the actual introduction and marketing of products and services reduces uncertainty about the business idea itself, and as the firm develops its business model successfully, implements administrative structures, and achieves more well-defined positions (Sine, Mitsuhashi, and Kirsch 2006). On the other hand, other authors have illustrated the lasting imprint that founders make on both the structure of top management teams as well as outcomes (Beckman and Burton 2008). Regardless, whether we consider the lifecycle theories of firm development or the lasting importance of founder imprinting events, ventures are not uniform in the extent to which specific individuals are important to the venture's performance as the organization matures. For some ventures, the knowledge founders hold remains an important determinant of success beyond the startup stage, and in some cases, founders may be less easily replaced or substituted for as compared to other cases.

This study makes specific predictions regarding how the use of TSK by a firm will influence the likelihood that founders we hold specific positions at IPO. We start with the CTO. The CTO has the most experience applying TSK toward the development of the products 
and services of the firm's portfolio. A non-founder, even with formal training in the same technical domain, would be less likely to have the same experience applying TSK to address opportunities and challenges faced by the firm, both for current products on the market as well as others envisioned for the pipeline down the road.

H1: A positive relationship will exist between the use of technical specialized knowledge (TSK) in the firm and the likelihood that the chief technology officer will be a founder at IPO.

In addition to the CTO, the CEO and CFO are also more likely to be founders at IPO in ventures where the application of TSK is important to commercial success. This is the case as the CEO and CFO are acting as a team in the IPO process, along with the CTO, to assure capital providers that the firm can be managed well through the planned growth phases, including further technological development, from not only the capital management and allocation perspectives, but also the product market and business model perspectives as well. The greater the amount of TSK involved in the process at the firm, the more varied the potential outcomes may be if those leading the overall strategic direction and financial management of the firm do not have a substantial grasp of the underlying technology.

The responsibilities of the CEO are generally to formulate strategy and the implementation of strategy, while the responsibilities of the CFO are generally to assure ongoing financial viability, manage cash flow, and guide budgeting decisions. To perform these functions, CEOs and CFOs must develop an understanding of various activities of the businesses and how these activities relate to the performance of the firm. In firms where TSK is important to commercial success, CEOs and CFOs, as they perform these functions over time, develop a unique understanding of the interface between the technical capabilities of the venture and commercial markets which can be difficult to transfer to other parties. For example, as changes in the marketplace render certain products less viable, the CEO must understand how a firm's technology can be utilized to target other product categories, consider strategic alliances that will enhance success, or invest more deeply in alternative or complementary activities. These decisions must be made swiftly. In these situations, the CFO must be able to navigate the banking and other capital provider relationships to articulate how the firm will succeed in the face of adversity, and understand the capital budgeting implications of a change in direction, based on the current technological position. While any CEO or CFO may acquire TSK as a result of these interactions, to the extent they already have the TSK to interface between the technical capabilities of the firm and commercial markets, the more likely the firm will be to succeed.

Hence, the capabilities of the founder CEOs and CFOs in developing an understanding of the interface between TSK and the commercial markets targeted by the firm makes them less likely to be replaced by non-founder professional managers. While non-founder professional managers may have greater general management knowledge, in comparison to the founder CEO and the founder CFO, they are less likely to understand the interface between TSK and outcomes important to the firm. While investors may attempt to recruit a new CEO with TSK and management knowledge, we suspect this will be difficult. Further, based on the complexity of TSK, professional managers are unlikely to be able to acquire this knowledge quickly.

H2: A positive relationship will exist between the use of technical specialized knowledge (TSK) in the firm and the likelihood that the chief executive officer will be a founder at IPO.

H3: A positive relationship will exist between the use of technical specialized knowledge (TSK) in the firm and the likelihood that the chief financial officer will be a founder at IPO.

\section{R\&D Intensity, the search for new knowledge}

Conceptually, research and development (R\&D) is the planned search for new knowledge or the translation of known knowledge for the purpose of creating a new commercially relevant improved product, service, process, or technique. Formally, the Statement of Federal Accounting Standards Board (FASB) defines $R \& D$ during the period of our study as the:

...planned search or critical investigation aimed at discovery of new knowledge that could result in a new or improved product, service, process, or technique. The development component of $R \& D$ is translating "research findings or other knowledge into a plan or design" for a new or improved product, service, process, or technique. (FASB 1974) 
Research and development expenditures are different from TSK in two fundamental ways. First, R\&D expenditures represent the extent that a firm is investing in the search for new knowledge for a specific purpose, but it does not capture all types of knowledge utilized by the firm. A biotechnology firm for example, may utilize TSK to search for a new product or service, while a restaurant may also invest in the search of a new product or service without utilizing TSK. Second, R\&D does not measure the extent to which the core technology of a firm is based on TSK, especially if it is not searching for new knowledge at a specific point in time. For example, one or more products of a firm that have been spun out of a university may be closely based on the TSK of a scientific founder, even if the firm incurs no additional $R \& D$ expenditures during some periods.

Given these important differences, we postulate that a different pattern will hold regarding the relationship between R\&D expenditures and the likelihood that a founder will hold specific executive positions at IPO than we proposed regarding the relationship between TSK and the same dependent variables. For founders who held the CTO position, because their job responsibilities include working with other technicians to search for knowledge, developing new products, and refining service, a high level of $R \& D$ activity increases the importance of the CTO position. Since founder CTOs have worked for the firms since the founding date of the firms, founder CTOs have built firm-specific knowledge that is unique and valuable not only for future R\&D investment but also for future knowledge search. In addition, achieving the milestone of approaching a potential IPO shows that such CTOs have done an excellent job in helping the firms make a successful move. Consequently, the greater R\&D expenditures, the greater the likelihood of that founder CTOs are retained through IPO.

H4: A positive relationship will exist between $R \& D$ expenditures and the likelihood that the chief technology officer will be a founder at IPO.

Unlike CTOs who are directly responsible and deeply engaged in the process of searching for new knowledge through R\&D, CEOs and CFOs have different responsibilities. When $R \& D$ investment increases, the complexity of the job requirement for CEOs and CFOs will also change. For example, when a company increases the R\&D investment, CEOs need to make a number of strategic changes to maximize the value of R\&D investments. As one strategy for instance, to protect the acquired new knowledge or newly developed product, CEOs have to come up with plans to apply for patents and other property protection procedures. When the newly developed products are successful, the CEOs also need to coordinate with other executives to design appropriate incentive plans to keep and motivate employees to contribute to the development of new products.

In addition to planning for potential success, the CEO also needs to prepare for failure. For instance, if the $R \& D$ activity does not generate expected profits, how would the firm change the effort of $R \& D$ investment? Many of these skills require years of experience in executive positions. Because founder CEOs typically have less experience to handle the complexity of the job involving a high level of R\&D activity, investors and other shareholders will have the preference to recruit outsiders with similar experience that can manage the complexity caused by the increasing R\&D activity. Unlike the CTO's responsibility, which is more firmspecific, the responsibility of the CEO is more generalized and less firm-specific knowledge is required.

In addition, Heeley, Matusik and Jain's (2007) study documented that R\&D spending increases the risk of underpricing of shares offered by the firm at IPO. They reasoned that the underpricing was largely due to increased information asymmetry driven by R\&D. Certo, Covin, Daily, and Dalton (2001) found that founder CEOs are believed to be less able to manage public firms, which could lead to further underpricing. Therefore, when a firm is pursuing a strategy of increasing R\&D expenditures, to avoid further underpricing, the shareholders will push the firm to replace founder CEOs with professional managers. This approach is widely believed to be a good signal for outside investors to build confidence in the newly public firms. These professional CEOs can manage the firm within the complicated situation. Thus, we expect that R\&D will decrease the likelihood of founders still being CEOs at the time of IPO.

H5: A negative relationship will exist between $R \& D$ expenditures and the likelihood that the chief executive officer will be a founder at IPO.

Much different from the responsibility of the CTO, the 
primary responsibilities of the CFO are to standardize, improve, and manage financial issues for a firm. As a firm grows large and complex, the CFO is responsible for managing financial risk. R\&D spending can lead to the discovery of new products, improvements to processes, and the development of new opportunities -all of which increase the complexity of the firm including the financing needs of the firm. Because a founder CFO typically has less experience and knowledge to deal with financial complexity caused by $R \& D$ expenditures than a professional manager, the shareholders will search for professional CFOs to replace founder CFOs if $R \& D$ expenditures increases.

H6: A negative relationship will exist between $R \& D$ expenditures and the likelihood that the chief financial officer will be a founder at IPO.

\section{The Paradox of Success}

Our data provides us the opportunity to examine in a broad sample comprised of many industries and years a driver of the paradox of success hypothesis that Wasserman (2003) found using a single-industry crosssectional survey as well as an additional potential mechanism. The paradox of success argument is that founder CEOs are often replaced after successfully achieving important business goals, such as completing product development or successfully raising outside funds. A benefit of Wasserman's work is that his analysis is based on a custom survey designed to examine specific business events that might drive the paradox of success. A limitation of his work is that the findings are based on a sample of 202 internet companies collected at a single point in time. Hence, the results might be driven by the attributes of the specific firms or industry he studied or by something unique about the short period of time that he studied. Our data provides us with the opportunity to examine two potential paradoxes of success - the number of round of outside funding achieved and the sales growth rate of the firm-in a sample of over 2,000 firms representing most industries over an 11 year period. A limitation of our work when compared to Wasserman's (2012) study is that we are only able to investigate two potential paradoxes - he examined five - that may be associated with increased rates of founder CEO transition.

\section{DATA AND METHODS Data}

We manually constructed a sample of demographic and transactional information on 2,217 firms that completed an IPO spanning the period from 1992 through 2002. We use this period due to data availability and because this historical period captures a time when Initial Public Offerings were sufficiently frequent to draw robust inferences (J. Ritter 2017). Following prior literature, we dropped unit offerings, ADRs, financial firms, closedend mutual funds, REITs, spinoffs, and reverse leveraged buyouts from our analysis of firms that achieved an IPO (J. R. Ritter and Welch 2002; Fischer and Pollock 2004). Our sample includes information extracted manually from paper filings that predates electronic filings at the Security Exchange Committee (SEC). We obtained information on the backgrounds of executive positions at IPO, including their classification as a founder of the firm. Initial public offering information was calculated from the Global New Issues database provided by Thomson Financial Securities Data Company (SDC) during the period 1992-2002, and VC information was collected from the same firm's VentureXpert database.

\section{Dependent variables}

Dichotomous variables were created to capture whether founders were still in the CEO, CFO, or CTO positions at the time the firm went public. Founder CEO or CFO was coded as one when the background information from the SEC registration filing showed that the firm's CEO or CFO was also the firm's founder. We coded Founder CTO in a similar way as Founder CEO only with regard to the highest ranking technology-related officer. Because not all firms consistently identify executives who are responsible for technology or science as a CTO, we also included in our CTO other positions such vice president (VP) of science, VP of research, or VP of R\&D.

\section{Hypothesized Variables}

Following prior literature (Junkunc and Eckhardt 2009), we used the prevalence of individuals holding a PhD. in the top management team as our measure of the technical specialized knowledge (TSK) of the firm. Per Hambrick and D'Aveni (1992), executives are classified as top management team members if they hold a title of vice president or higher. Specifically, we measured TSK by calculating the number of executives who have PhD. degrees. We follow Delios and Beamish (1999) by calculating our $R \& D$ measure as the natural log of the ratio of $R \& D$ expenditures for each firm in the year of IPO divided by the number of employees at the firm. 


\section{Control Variables}

As venture capitalists often prefer to invest in technically intensive firms (Gompers and Lerner 2001), we include as a control the dichotomous variable venture backed, which is set to 1 if the firm received financing from venture capitalists and set to zero otherwise. We include $N A S D A Q$ as a dummy variable to control for potential differences in preferences by different exchanges regarding founder management at IPO. Loughran and Ritter's (2004) underwriter prestige measure was included to differentiate the reputation of underwriters as more prestigious underwriters may have the ability to force founder CEO succession. We also created a dummy variable to capture whether the firm has achieved profit at the year of IPO. Profit was set to 1 if the firm's income exceeded the total costs and was set to 0 otherwise. We calculated natural log of company sales in the year of the offering in millions of dollars to account for firm size. Corporate governance literature has documented the evidence that percentage of the firm owned by insiders has an important effect on CEO turnover (Finkelstein, Hambrick, and Cannella 2009). We therefore controlled for insider percentage in the year of offering (pre-IPO). An insider is defined as a director or one who serves as an executive officer. We also controlled for firm age and firm age squared to account for the age effect on the likelihood of executive turnover. We took a natural log transformation of age and age squared to have a less skewed distribution of these variables.

Finally, we controlled for industry and time by including dummy variables for industry and years. For industry, we included dummy variables to account for whether the newly public firms were operating in the following industries: medical equipment, pharmaceutical products, business services, computer hardware, computer software, and electronic equipment. We include dummy variables for years between 1993 and 2002 with year 1992 as reference category. For readability, we omit the year coefficients from our regression tables. Lastly, to control for regional differences in the propensity for executives to be replaced, we coded regional dummies based on whether the firms were started in the west coast or norteast.

\section{Measuring Wasserman's Paradox of Success}

We include in our analysis two covariates to assess the validity of Wasserman's paradox of success in our sample. The first, VC Rounds, is the count of the number of rounds of investment which we compute from data provided by VentureXpert database. This is essentially the same construct that was included in Wasserman's (2003) paper. If raising rounds of outside capital is deemed to be a successful outcome, the paradox would be that firms that have successfully completed more rounds of financing were less likely to have founders in executive positions. The second covariate we include to assess the paradox of success is sales growth, which is measured as total sales at IPO divided by firm age. Because of the skew of the sales growth, we took a log transformation of the original sales growth.

This measure was not included in Wasserman's original paper. The closest measure he used in his analysis was a measure of product development. We include this measure as rapidly growing firms are difficult to manage in part because they require rapid decision making and formalized management systems, and they provide less time for founders to learn important managerial skills on the job.

\section{Analysis}

Because our dependent variables are dichotomous variables measuring whether the executives were founders, we used the probit model to test our hypotheses. Since every public firm has a CEO and a CFO, we do not have a selection issue for founder CEO and founder CFO hypotheses. However, because not all firms have a CTO, we first model the existence of the CTO, and we then investigate if the position is held by a founder or not. In our sample, we identified that 1,142 companies had a CTO positions.

To address this potential selection bias, we employed two-stage Heckman selection models using STATA's heckprobit procedure (Heckman 1979). The first-stage probit model predicts whether the firm has a CTO position; estimates of the parameters from the first stage were then incorporated into the second-stage probit model to predict whether a founder is currently the CTO (Van de Ven and Van Praag 1981). A requirement of the Heckman procedure is that at least one selection variable should be included in the analysis that predicts the likelihood of selection, but not the ultimate dependent variable of interest. Otherwise, the Heckman selection model tends to produce biased estimators (Stolzenberg and Relles 1997). In our analysis, we 
found two measures that satisfied these requirements. For the first-stage models, we used high technology dummy and number of employees to predict the likelihood of existence of a technological position. High technology dummy was set to 1 if the company was a high-tech company (determined by SDC) and set to 0 if not. Number of employees was calculated as the number of employees at the year of IPO.

\section{RESULTS}

Table 1 reports our descriptive statistics and Table 2 reports bivariate correlations. Table 1 indicates that approximately 47 percent of the firms had founders as the CEO at IPO. Additionally, around 11 percent of the CFOs and 18 percent of the CTOs were founders at the time of IPO. Excepting the correlation between age and age square and sales and sales growth, all the correlation coefficients are under 0.5.

\section{Founder CTO}

Table 3 reports two-stage Heckman selection models to test our hypotheses related to CTO turnover. The first column is the second stage regression and the second column is the first stage regression for each paired model. The likelihood-ratio test represents a test of the joint likelihood of an independent probit model for the selection equation and a standalone regression model vs. the integrated two-step Heckman model we use here. The test rejects the null hypothesis across all models reported in Table 3, which supports the use of the Heckman selection model that we use here. As for controls, we found firm age has a concave downsloping effect on the likelihood of founders being CTOs. Few other control variables predict the likelihood that founders will be CTO at the time of IPO. There is evidence that some industries both predict the existence of the CTO position and if the founder holds the position at IPO. For example, a firm in the Medical Equipment industry is more likely to have CTO position at IPO and it is less likely that this position will be held by a founder than a firm formed in the Computer Hardware industry. Interestingly, insider percentage is positively associated with a founder being the CTO at IPO.

The analysis in Table 3 demonstrates mixed evidence in support of $\mathrm{H1}$, which hypothesizes a positive relation between TSK and the likelihood of founders being CTO. After controlling for other hypothesized effects as shown in columns 9 and 10, one more PhD in the top executive team will increase the likelihood that founders will be CTO by 5.4 percent. However the null hypothesis of no effect is rejected in the base model shown in columns 1 and 2 of Table 2.

After modeling for the existence of the CTO position, Models 3 and 9 report no evidence that supports our prediction $(\mathrm{H} 4)$ about the relation between $R \& D$ intensity and likelihood of founders being CTO as we fail to reject the null hypothesis of no effect in this case. Founder-CEO

Table 4 summarizes our test of the founder CEO retention hypotheses. As for control variables, we found evidence that a higher percentage of insiders on the board increases the likelihood of founders being CEOs. Firm age is estimated as having a predominantly positive, concave downward sloping relation to the likelihood of founders being CEOs at IPO. We find that CEOs are less likely to be founders at IPO in venturebacked firms. Consistent with our $\mathrm{H} 2$ prediction, there is a positive and significant relationship between TSK and likelihood of founders being CEO. Model 1 of Table 4 demonstrates that one more $\mathrm{PhD}$ in the executive team will increase the likelihood that founders will be CEOs by 2.3 percent. As predicted in H5, Model 2 reports the evidence that $R \& D$ decreases the likelihood of founders being CEO at IPO but the effect size is not large. Overall, the analysis in Table 4 (See Appendix) indicates that TSK and R\&D play opposite roles in determining whether founders will be CEOs at the time of IPO.

Table 5 summarizes our findings for testing founder CFO retention. None of the control variables, except for the northeast dummy and underwriter prestige, predict the likelihood of founder CFO retention. Model 1 and 5 of Table 5 confirms the prediction that TSK is positively and significantly related to the likelihood of founder CFO retention (H3). While Model 2 shows no support for our prediction that R\&D negatively affects the likelihood of founder CFO retention ( $\mathrm{H} 6)$, there is support found for this hypothesis in the full model in model 5.

\section{Evidence on the Paradox of Success}

We find no relationship between Sales Growth and founder retention across all models reported in Tables 3 through 5 for all executive positions studied. Hence, based on our analysis one might infer that founders are able to learn how to grow their skills even if firms grow rapidly. In contrast, we do find a negative relationship between the number of VC rounds raised and the 
likelihood that a founder will hold an executive position for both the CEO and CFO positions. Specifically, one more round invested by VCs will decrease the likelihood that a founder is the CEO or CFO by 2.8 percent (Model 4 of Table 4) and 1.2 percent (Model 4 of Table 5), respectively. This finding echoed the conclusion by Hellmann and Puri (2002) who found that VCs helped companies to professionalize by replacing founders with professional managers. In terms of the CTO position, we find that the number of $\mathrm{VC}$ rounds raised is positively associated with the existence of the CTO position, but we failed to find that it influences whether the position is held by the founder or not. One inference from the analysis of the $\mathrm{VC}$ rounds measure is that the need to raise an additional round may reflect a failure to secure sufficient revenue, and hence interpreting $V C$ rounds as a paradox of success may be inappropriate.

\section{Limitations}

This paper is not without limitations. First, the sample we used to test our theory comes from newly public firms from a historical database. Hence it may not be possible to generalize our findings to non-public firms, large firms such as those in the Fortune 500 which have been publicly traded for many years, or to periods outside the years we studied. Additionally, because our sample comes from the U.S. market, our results might not hold in countries other than the U.S. It would be interesting to understand whether country culture and legal system will affect the retention of founder executives. Second, compared to incumbents, newly public firms are relatively small, making it extremely difficult to track down executive information before IPO. It would be valuable for future research to investigate the evolution of executives in new firms. Third, this paper does not examine how the ability for investors and founders to exit a firm may differ if a firm is acquired instead of achieving an IPO. Given that more firms are acquired than achieve IPO, this is an important issue that warrants addition theoretical and empirical work. To speculate, the characteristics of acquiring firms may matter. For example, acquiring firms that already possess relevant TSK may provide greater opportunities for investors and founders to exit than acquiring firms that lack relevant TSK.

\section{CONCLUSION}

Our research makes several contributions to research in entrepreneurship and strategy. First, we extended Wasserman's (2003) findings by including firms from multiple industries over a period of 11 years. Our empirical evidence showed that a potentially stable characteristic of firms, technical specialized knowledge, is a generally robust predictor of founder CEO transition when compared to success measures such as sales growth. Our findings are more general than Wasserman's results in that we focus on a broad range of industries rather than just the Internet industry. Furthermore, our multi-year study can also better account for the factors correlated with time, such as the first Internet bubble.

Second, rather than focusing on only CEOs, we extended prior research to other crucial executive positions, namely CTOs and CFOs, with distinct theoretical motivators. Our results show that TSK of firms predicted whether founders remained as CTOs and CFOs as well at the time of IPO. In addition, TSK is positively related to the likelihood of founder CEO retention. By differentiating knowledge embedded within executives (TSK) and search activity (R\&D), we predict and find that $R \& D$ plays a different role in determining retention of founder CTOs, CFOs, and founder CEOs.

Third, we contributed to executive turnover literature by using different explanatory variables. Finkelstein, Hambrick, and Cannella (2009) summarized the executive turnover literature by showing that firm performance, agency conditions, environment, and predecessor characteristics were potential antecedents of executive turnover. Our empirical results indicate that TSK, R\&D intensity, and the number of VC rounds invested in the company generally influence executive succession. Finkelstein et al. (2009) also called for more research on examining executive turnover beyond CEOs. Moreover, they also suggested that additional studies using representative samples other than Fortune or S\&P are needed to further explore executive turnover. Our study contributes to executive turnover literature by using a different sample to study succession of multiple executive positions.

Acknowledgements: We thank the research assistance provided by Sara Jane Wilcox, Susan Gagliardi, Michael Kochevar, Arad Usha, Gokce Kuruku and the Baker Library at Harvard University for access to data. The first author appreciates funding that was provided by the Richard M. Schulze Family Foundation that supported this research.

\section{REFERENCES}


Barney, J. 1991. "Firm Resources and Sustained Competitive Advantage." Journal of Management 17 (1): 99-121.

Becker, Gary S. 1994. Human Capital: A Theoretical and Empirical Analysis, with Special Reference to Education, 3rd Edition. Third edition. University of Chicago Press.

Becker, G., and K. Murphy. 1992. "The Division of Labor, Coordination Costs and Knowledge." The Quarterly Journal of Economics 107: 1137-60.

Beckman, Christine M., and M. Diane Burton. 2008. "Founding the Future: Path Dependence in the Evolution of Top Management Teams from Founding to IPO." Organization Science 19 (1): 3-24.

Certo, S. Trevis, Jeffrey G. Covin, Catherine M. Daily, and Dan R. Dalton. 2001. "Wealth and the Effects of Founder Management among IPO-Stage New Ventures." Strategic Management Journal 22 (6-7): 641-58.

Chandler, Alfred Dupont. 1977. The Visible Hand: The Managerial Revolution in American Business. Cambridge, Mass.: Belknap Press.

Churchill, N., and V. Lewis. 1983. "The Five Stages of Small Business Growth." Harvard Business Review 16 (3): 30-39.

Cohen, Wesley, R. Nelson, and J. Walsh. 2002. "Links and Impacts: The Influence of Public Research on Industrial R\&D." Management Science 48 (1): 1-23.

Delios, Andrew, and Paul W. Beamish. 1999. "Ownership Strategy of Japanese Firms: Transactional, Institutional, and Experience Influences." Strategic Management Journal 20 (10): 915-33.

Eckhardt, Jonathan T., and Scott A. Shane. 2003. "Opportunities and Entrepreneurship." Journal of Management 29 (3): 333-49.

FASB. 1974. "The Accounting for Research and Development Costs."

Finkelstein, Sydney, Donald C. Hambrick, and Albert A. Cannella. 2009. Strategic Leadership: Theory and Research on Executives, Top Management Teams, and Boards. Oxford University Press.
Fischer, Harold M., and Timothy G. Pollock. 2004. "Effects of Social Capital and Power on Surviving Transformational Change: The Case of Initial Public Offerings." Academy of Management Journal. Academy of Management 47 (4): 463-81.

Gompers, Paul, and Josh Lerner. 2001. "The Venture Capital Revolution." The Journal of Economic Perspectives: A Journal of the American Economic Association 15 (2): 145-68.

Graham, Paul. 2010. Hackers \& Painters: Big Ideas from the Computer Age. 1 edition. O'Reilly Media.

Hambrick, Donald C., and Richard A. D’Aveni. 1992. "Top Team Deterioration as Part of the Downward Spiral of Large Corporate Bankruptcies." Management Science 38 (10): 1445-66.

Heckman, J. 1979. "Sample Selection as a Specification Error." Econometrica: Journal of the Econometric Society 47 (1): 153-62.

Heeley, M., S. Matusik, and N. Jain. 2007. "Innovation, Appropriability, and the Underpricing of Initial Public Offerings." Academy of Management Journal. Academy of Management 50 (1): 209-25.

Hellmann, Thomas, and Manju Puri. 2002. "Venture Capital and the Professionalization of Start-up Firms: Empirical Evidence." The Journal of Finance 57 (1): 169-97.

Junkunc, M., and J. Eckhardt. 2009. "Technical Specialized Knowledge and Secondary Shares in Initial Public Offerings." Management Science 55 (10): 1670-87.

Klevorick, Alvin, R. Levin, R. Nelson, and S. Winter. 1995. "On the Sources and Significance of Interindustry Differences in Technological Opportunities." Research Policy 25: 185-205.

Kroll, Mark, Bruce Walters, and Son A. Le. 2007. "The Impact of Board Composition and Top Management Team Ownership Structure on Post-IPO Performance in Young Entrepreneurial Firms." Academy of Management Journal. Academy of Management 50 (5): 1198-1216.

Lindsay, Peter H., and Donald A. Norman. 1977. Human Information Processing. Orlando, FL: Academic Press. 
Loughran, T., and Jay R. Ritter. 2004. "Why Has IPO Underpricing Changed over Time?" Financial Management 33 (3): 5-37.

Michael, S. 2012. "Monitoring Technical Managers: Theory, Evidence, and Prescriptions." Journal of High Technology Management 26: 36-45.

Ritter, J. 2017. "Founding Dates for 12,719 Firms Going Public in the U.S. during 1975-2016."

Ritter, Jay R., and I. Welch. 2002. "A Review of IPO Activity, Pricing, and Allocations." The Journal of Finance 57 (4): 1795-1828.

Shane, S., and D. Cable. 2002. "Network Ties, Reputation, and the Financing of New Ventures." Management Science 48 (3): 364-81.

Shane, Scott. 2000. "Prior Knowledge and the Discovery of Entrepreneurial Opportunities." Organization Science 11 (4): 448-69.

Sine, Wesley D., Hitoshi Mitsuhashi, and David A. Kirsch. 2006. "Revisiting Burns And Stalker: Formal Structure And New Venture Performance In Emerging Economic Sectors." Academy of Management Journal. Academy of Management 49 (1): 121-32.

Stolzenberg, Ross M., and Daniel A. Relles. 1997. "Tools for Intuition about Sample Selection Bias and Its Correction." American Sociological Review 62 (3): 494-507.

Van de Ven, Wynand P. M. M., and Bernard M. S. Van Praag. 1981. "The Demand for Deductibles in Private Health Insurance." Journal of Econometrics 17 (2): 229-52.

Venkataraman, Sankaran. 1997. "The Distinctive Domain of Entrepreneurship Research." In Advances in Entrepreneurship, Firm Emergence and Growth, edited by J. Katz and R. Brockhaus, 3:119-38. Greenwich, CT: JAI Press.

Wasserman, Noam. 2003. "Founder-CEO Succession and the Paradox of Entrepreneurial Success." Organization Science 14 (2): 149-72.

-_-. 2012. "Chapters 3 (solo vs. team),4 (Relationships), 6 (Equity Splits)." In The Founder's Dilemmas: Anticipating and Avoiding the Pitfalls That
Can Sink a Startup. Princeton University Press.

Winter, Sidney G. 1990. "Knowledge and Competence as Strategic Assets." In The Competitive Challenge: Strategies for Industrial Innovation and Renewal, edited by D. J. Teece. New York, NY: Harper \& Row, Publishers. 
TABLE 1: SUMMARY STATISTICS

\begin{tabular}{|c|c|c|c|c|}
\hline & Mean & S.D. & Min & Max \\
\hline CEO & 0.47 & 0.50 & 0.00 & 1.00 \\
\hline CFO & 0.11 & 0.31 & 0.00 & 1.00 \\
\hline СTO & 0.18 & 0.38 & 0.00 & 1.00 \\
\hline Total Ph. D. & 0.02 & 1.58 & -0.71 & 10.29 \\
\hline R\&D Intensity & 0.09 & 5.13 & -5.80 & 8.15 \\
\hline Sales Growth & 1.57 & 1.09 & 0.00 & 5.86 \\
\hline VC Rounds & 0.05 & 2.93 & -2.05 & 18.95 \\
\hline Venture-backed & 0.51 & 0.50 & 0.00 & 1.00 \\
\hline NASDAQ & 0.78 & 0.42 & 0.00 & 1.00 \\
\hline Underwriter Prestige & 6.82 & 2.46 & 1.00 & 9.10 \\
\hline Profitable @ IPO & 0.49 & 0.50 & 0.00 & 1.00 \\
\hline Sales (In) & 9.72 & 2.55 & 0.00 & 14.88 \\
\hline Insider Precentage & 63.44 & 26.50 & 0.00 & 100.00 \\
\hline Age $(\ln )$ & 2.05 & 0.88 & 0.00 & 4.75 \\
\hline West Coast & 0.40 & 0.49 & 0.00 & 1.00 \\
\hline North East & 0.26 & 0.44 & 0.00 & 1.00 \\
\hline Medical equipment & 0.06 & 0.24 & 0.00 & 1.00 \\
\hline Pharmaceutical products & 0.08 & 0.27 & 0.00 & 1.00 \\
\hline Business service & 0.09 & 0.29 & 0.00 & 1.00 \\
\hline Computer hardware & 0.04 & 0.19 & 0.00 & 1.00 \\
\hline Computer software & 0.28 & 0.45 & 0.00 & 1.00 \\
\hline Electronic equipment & 0.06 & 0.24 & 0.00 & 1.00 \\
\hline
\end{tabular}


TABLE 2: CORRELATION TABLE

\begin{tabular}{|c|c|c|c|c|c|c|c|c|}
\hline & (1) & (2) & (3) & (4) & (5) & (6) & (7) & (8) \\
\hline (1) CEO & 100 & & & & & & & \\
\hline (2) $\mathrm{CFO}$ & 0.24 & 1.00 & & & & & & \\
\hline (3) СТO & 0.03 & 0.10 & 1.00 & & & & & \\
\hline (4) Total Ph.D. & 0.04 & 0.02 & 0.22 & 1.00 & & & & \\
\hline (5) R\&D Intensity & -0.03 & -0.05 & 0.34 & 0.38 & 1.00 & & & \\
\hline (6) Sales Growth & 0.04 & -0.04 & -0.11 & .023 & -0.32 & 100 & & \\
\hline (7) vC Rounds & -0.09 & -0.09 & 0.19 & 0.27 & 0.42 & -0.11 & 100 & \\
\hline (8) Venture-backed & -0.02 & -0.07 & 0.22 & 0.21 & 0.44 & .002 & 0.71 & 100 \\
\hline (g) NASDAO & 0.03 & -0.10 & 0.11 & 0.13 & 0.17 & 0.17 & 0.24 & 0.31 \\
\hline (10) Underwriter Prestige & 0.01 & -0.24 & 0.11 & 0.13 & 0.19 & 0.37 & 0.32 & 0.39 \\
\hline (11) Profitable a IPO & -0.02 & -0.04 & -0.24 & -0.24 & -0.33 & 0.37 & -0.23 & -0.21 \\
\hline (12) Sales (In) & 0.00 & -0.09 & -0.24 & -0.23 & -0.36 & 0.71 & -0.11 & -0.05 \\
\hline (13) Insider Precentage & 0.13 & 0.04 & -0.07 & .0 .14 & .024 & 0.12 & .025 & -0.21 \\
\hline (24) Age (In) & $=0.09$ & -0.10 & -0.10 & .0 .07 & -0.13 & $=0.19$ & -0.06 & -0.09 \\
\hline (15) Age (In, squared) & .0 .12 & -0.10 & -0.13 & -0.11 & .0 .20 & $=0.14$ & -0.12 & -0.15 \\
\hline (16) West Coast & 0.02 & -0.06 & 0.16 & 0.13 & 0.26 & -0.04 & 0.21 & 0.17 \\
\hline (17) North East & 0.01 & 0.09 & -0.04 & 0.01 & -0.00 & -0.07 & -0.00 & 0.01 \\
\hline (18) Medical equipment & -0.04 & -0.00 & 0.06 & 0.06 & 0.20 & -0.18 & 0.14 & 0.12 \\
\hline (19) Pharmaceutical products & -0.02 & 0.01 & $\infty .00$ & 0.49 & 0.30 & .0 .25 & 0.19 & 0.15 \\
\hline (20) Business service & 0.01 & 0.00 & -0.07 & 0.07 & .0 .07 & -0.01 & -0.01 & -0.01 \\
\hline (21) Computer hardware & -0.01 & -0.02 & 0.07 & .0 .01 & 0.15 & -0.00 & 0.02 & 0.05 \\
\hline (22) Computer software & 0.05 & -0.02 & 0.18 & .0 .10 & 0.30 & 0.01 & 0.15 & 0.21 \\
\hline \multirow[t]{2}{*}{ (23) Electronic equipment } & -0.01 & -0.03 & 0.07 & 0.04 & 0.15 & 0.04 & 0.07 & 0.05 \\
\hline & (g) & (10) & (11) & (12) & (13) & (14) & (15) & \\
\hline (9) NASDAQ & 100 & & & & & & & \\
\hline (10) Underwriter Prestige & 0.52 & 1.00 & & & & & & \\
\hline (11) Profitable ब IPO & 0.09 & 0.09 & 1.00 & & & & & \\
\hline (12) Sales (In) & 0.21 & 0.38 & 0.48 & 1.00 & & & & \\
\hline (13) Insider Pecentage & -0.05 & -0.08 & 0.17 & 0.15 & 1.00 & & & \\
\hline (24) Age (In) & 0.06 & 0.13 & 0.32 & 0.32 & 0.05 & 1.00 & & \\
\hline (15) Age (In, squared) & 0.03 & 0.10 & 0.34 & 0.34 & 0.06 & 0.96 & 100 & \\
\hline (16) West Coast & 0.09 & 0.13 & -0.08 & -0.04 & -0.11 & -0.09 & -0.11 & \\
\hline (17) North East & -0.06 & -0.07 & -0.07 & -0.07 & 0.00 & -0.02 & -0.02 & \\
\hline (18) Medical equipment & 0.01 & -0.01 & -0.12 & -0.20 & -0.07 & -0.01 & -0.03 & \\
\hline (19) Pharmaceutical products & 0.02 & 0.02 & -0.21 & .0 .33 & .014 & .0 .07 & -0.09 & \\
\hline (20) Business service & -0.01 & $=0.01$ & $=0.04$ & .0 .01 & 0.00 & .0 .02 & -0.01 & \\
\hline (21) Computer hardware & -0.02 & -0.06 & 0.00 & .0 .02 & .0 .03 & .0 .02 & .003 & \\
\hline (22) Computer software & 0.16 & 0.17 & -0.09 & 0.06 & 0.01 & -0.09 & -0.13 & \\
\hline \multirow[t]{2}{*}{ (23) Electronic equipment } & 0.07 & 0.05 & 0.11 & 0.07 & -0.06 & 0.06 & 0.04 & \\
\hline & (16) & $(17)$ & (18) & (19) & (20) & (21) & (22) & \\
\hline (16) West Coast & 100 & & & & & & & \\
\hline (17) North East & -0.48 & 100 & & & & & & \\
\hline (18) Medical equipment & 0.06 & -0.04 & 1.00 & & & & & \\
\hline
\end{tabular}


TABLE 3: FOUNDER-CTO RETENTION (Heckman)

\begin{tabular}{|c|c|c|c|c|c|c|c|c|c|c|}
\hline & (1) & (2) & (3) & (4) & (5) & (6) & (7) & (8) & (9) & (10) \\
\hline Venture-backed & $\begin{array}{l}-0.047 \\
(0.09)\end{array}$ & $\begin{array}{c}0.321 \cdots \\
(0.07)\end{array}$ & $\begin{array}{c}-0.029 \\
(0.09)\end{array}$ & $\begin{array}{c}0.215^{\cdots} \\
(0.08)\end{array}$ & $\begin{array}{l}-0.078 \\
(0.09)\end{array}$ & $\begin{array}{c}0.318^{\cdots *} \\
(0.07)\end{array}$ & $\begin{array}{l}0.008 \\
(0.10)\end{array}$ & $\begin{array}{l}0.217^{* *} \\
(0.09)\end{array}$ & $\begin{array}{l}0.078 \\
(0.11)\end{array}$ & $\begin{array}{l}0.159^{\circ} \\
(0.10)\end{array}$ \\
\hline NASDAQ & $\begin{array}{c}-0.139 \\
(0.12)\end{array}$ & $\begin{array}{c}0.266^{*} \\
(0.09)\end{array}$ & $\begin{array}{l}-0.111 \\
(0.12)\end{array}$ & $\begin{array}{c}0.315^{\cdots} \\
(0.09)\end{array}$ & $\begin{array}{l}-0.104 \\
(0.12)\end{array}$ & $\begin{array}{c}0.298^{*} \\
(0.09)\end{array}$ & $\begin{array}{c}-0.102 \\
(0.12)\end{array}$ & $\begin{array}{c}0.305^{\cdots} \\
(0.09)\end{array}$ & $\begin{array}{l}-0.145 \\
(0.12)\end{array}$ & $\begin{array}{c}0.280 \cdots \\
(0.09)\end{array}$ \\
\hline Underwriter Prestige & $\begin{array}{l}-0.027 \\
(0.02)\end{array}$ & $\begin{array}{c}0.093^{\cdots} \\
(0.02)\end{array}$ & $\begin{array}{l}-0.019 \\
(0.02)\end{array}$ & $\begin{array}{c}0.074^{\cdots} \\
(0.02)\end{array}$ & $\begin{array}{l}-0.031 \\
(0.02)\end{array}$ & $\begin{array}{c}0.107^{*} \cdot \\
(0.02)\end{array}$ & $\begin{array}{l}-0.027 \\
(0.02)\end{array}$ & $\begin{array}{c}0.099^{\cdots} \\
(0.02)\end{array}$ & $\begin{array}{l}-0.020 \\
(0.02)\end{array}$ & $\begin{array}{c}0.073^{\cdots} \cdot \\
(0.02)\end{array}$ \\
\hline Profitable @ IPO & $\begin{array}{l}0.172^{*} \\
(0.09)\end{array}$ & $\begin{array}{c}-0.177^{*} \\
(0.08)\end{array}$ & $\begin{array}{l}0.118 \\
(0.09)\end{array}$ & $\begin{array}{c}-0.188^{*} \\
(0.08)\end{array}$ & $\begin{array}{l}0.141 \\
(0.09)\end{array}$ & $\begin{array}{c}-0.182^{*} \\
(0.08)\end{array}$ & $\begin{array}{l}0.145 \\
(0.09)\end{array}$ & $\begin{array}{c}-0.197^{*} \\
(0.08)\end{array}$ & $\begin{array}{l}0.129 \\
(0.10)\end{array}$ & $\begin{array}{l}-0.152^{\prime} \\
(0.08)\end{array}$ \\
\hline Sales (in) & $\begin{array}{l}0.002 \\
(0.02)\end{array}$ & $\begin{array}{c}-0.115^{* *} \\
(0.02)\end{array}$ & $\begin{array}{l}-0.008 \\
(0.02)\end{array}$ & $\begin{array}{c}-0.072^{\cdots} \\
(0.02)\end{array}$ & $\begin{array}{l}-0.000 \\
(0.02)\end{array}$ & $\begin{array}{c}-0.103^{\cdots} \\
(0.02)\end{array}$ & $\begin{array}{l}0.003 \\
(0.02)\end{array}$ & $\begin{array}{c}-0.125^{\cdots} \\
(0.02)\end{array}$ & $\begin{array}{l}-0.019 \\
(0.02)\end{array}$ & $\begin{array}{c}-0.053^{* *} \\
(0.03)\end{array}$ \\
\hline Insider Precentage & $\begin{array}{l}0.003^{\circ "} \\
(0.00)\end{array}$ & $\begin{array}{c}-0.003^{\cdots} \\
(0.00)\end{array}$ & $\begin{array}{c}0.003^{*} \\
(0.00)\end{array}$ & $\begin{array}{c}-0.003^{*} \\
(0.00)\end{array}$ & $\begin{array}{l}0.003^{* *} \\
(0.00)\end{array}$ & $\begin{array}{c}-0.004^{\cdots} \\
(0.00)\end{array}$ & $\begin{array}{l}0.003^{*} \\
(0.00)\end{array}$ & $\begin{array}{c}-0.003^{\cdots} \\
(0.00)\end{array}$ & $\begin{array}{l}0.003^{\circ} \\
(0.00)\end{array}$ & $\begin{array}{c}-0.002^{\circ} \\
(0.00)\end{array}$ \\
\hline Age (In) & $\begin{array}{l}0.352^{* *} \\
(0.15)\end{array}$ & $\begin{array}{l}-0.044 \\
(0.11)\end{array}$ & $\begin{array}{l}0.371^{*} \\
(0.15)\end{array}$ & $\begin{array}{l}-0.093 \\
(0.12)\end{array}$ & $\begin{array}{l}0.400^{* *} \\
(0.16)\end{array}$ & $\begin{array}{c}-0.094 \\
(0.12)\end{array}$ & $\begin{array}{c}0.384^{\cdots} \\
(0.15)\end{array}$ & $\begin{array}{l}-0.021 \\
(0.11)\end{array}$ & $\begin{array}{c}0.378^{* *} \\
(0.16)\end{array}$ & $\begin{array}{c}-0.140 \\
(0.13)\end{array}$ \\
\hline Age (In, squared) & $\begin{array}{c}-0.121 \cdots \\
(0.04)\end{array}$ & $\begin{array}{l}0.023 \\
(0.03)\end{array}$ & $\begin{array}{c}-0.127^{\cdots} \\
(0.04)\end{array}$ & $\begin{array}{l}0.026 \\
(0.03)\end{array}$ & $\begin{array}{c}-0.128^{\cdots} \\
(0.04)\end{array}$ & $\begin{array}{l}0.020 \\
(0.03)\end{array}$ & $\begin{array}{c}-0.127^{\cdots} \\
(0.04)\end{array}$ & $\begin{array}{l}0.017 \\
(0.03)\end{array}$ & $\begin{array}{c}-0.123^{\cdots} \\
(0.04)\end{array}$ & $\begin{array}{l}0.030 \\
(0.03)\end{array}$ \\
\hline West Coast & $\begin{array}{l}0.075 \\
(0.09)\end{array}$ & $\begin{array}{l}0.117 \\
(0.08)\end{array}$ & $\begin{array}{l}0.104 \\
(0.09)\end{array}$ & $\begin{array}{l}0.043 \\
(0.08)\end{array}$ & $\begin{array}{l}0.097 \\
(0.09)\end{array}$ & $\begin{array}{l}0.138^{\circ} \\
(0.08)\end{array}$ & $\begin{array}{l}0.106 \\
(0.09)\end{array}$ & $\begin{array}{l}0.140^{\circ} \\
(0.08)\end{array}$ & $\begin{array}{l}0.103 \\
(0.09)\end{array}$ & $\begin{array}{l}0.014 \\
(0.08)\end{array}$ \\
\hline North East & $\begin{array}{l}0.014 \\
(0.10)\end{array}$ & $\begin{array}{l}-0.115 \\
(0.08)\end{array}$ & $\begin{array}{l}0.017 \\
(0.10)\end{array}$ & $\begin{array}{c}-0.156^{\circ} \\
(0.08)\end{array}$ & $\begin{array}{l}0.034 \\
(0.10)\end{array}$ & $\begin{array}{l}-0.124 \\
(0.08)\end{array}$ & $\begin{array}{l}0.033 \\
(0.10)\end{array}$ & $\begin{array}{l}-0.123 \\
(0.08)\end{array}$ & $\begin{array}{l}0.020 \\
(0.10)\end{array}$ & $\begin{array}{c}-0.157^{\circ} \\
(0.08)\end{array}$ \\
\hline Medical equipment & $\begin{array}{c}-0.333^{*} \\
(0.16)\end{array}$ & $\begin{array}{c}0.645^{\cdots} \\
(0.16)\end{array}$ & $\begin{array}{l}-0.177 \\
(0.16)\end{array}$ & $\begin{array}{c}0.348^{*} \\
(0.16)\end{array}$ & $\begin{array}{c}-0.338^{*} \\
(0.16)\end{array}$ & $\begin{array}{c}0.674 \cdots \\
(0.16)\end{array}$ & $\begin{array}{c}-0.327^{*} \\
(0.16)\end{array}$ & $\begin{array}{c}0.685^{\cdots} \\
(0.16)\end{array}$ & $\begin{array}{l}-0.168 \\
(0.16)\end{array}$ & $\begin{array}{c}0.334 * \\
(0.17)\end{array}$ \\
\hline Pharmaceutical products & $\begin{array}{c}-0.523^{\cdots} \\
(0.16)\end{array}$ & $\begin{array}{c}0.539 \cdots \\
(0.18)\end{array}$ & $\begin{array}{c}-0.249^{\circ} \\
(0.15)^{\circ}\end{array}$ & $\begin{array}{c}0.501 \cdots \\
(0.17)\end{array}$ & $\begin{array}{c}-0.424 \cdots \\
(0.15)\end{array}$ & $\begin{array}{c}0.856^{\cdots} \\
(0.17)\end{array}$ & $\begin{array}{c}-0.416^{\cdots} \\
(0.15)\end{array}$ & $\begin{array}{c}0.871 \cdots \\
(0.17)\end{array}$ & $\begin{array}{c}-0.378^{*} \\
(0.16)\end{array}$ & $\begin{array}{l}0.262 \\
(0.18)\end{array}$ \\
\hline Business service & $\begin{array}{c}-0.394^{*} \\
(0.15)\end{array}$ & $\begin{array}{l}0.206^{\circ} \\
(0.12)\end{array}$ & $\begin{array}{c}-0.275^{\circ} \\
(0.15)\end{array}$ & $\begin{array}{l}0.193 \\
(0.13)\end{array}$ & $\begin{array}{c}-0.337^{*} \\
(0.15)\end{array}$ & $\begin{array}{l}0.253^{* *} \\
(0.12)\end{array}$ & $\begin{array}{c}-0.336^{*} \\
(0.15)\end{array}$ & $\begin{array}{l}0.261 . " \\
(0.12)\end{array}$ & $\begin{array}{c}-0.330^{*} \\
(0.16)\end{array}$ & $\begin{array}{l}0.159 \\
(0.13)\end{array}$ \\
\hline Computer hardware & $\begin{array}{l}-0.221 \\
(0.19)\end{array}$ & $\begin{array}{c}0.809^{\cdots} \\
(0.18)\end{array}$ & $\begin{array}{l}-0.027 \\
(0.18)\end{array}$ & $\begin{array}{c}0.388^{*} \\
(0.19)\end{array}$ & $\begin{array}{l}-0.252 \\
(0.19)\end{array}$ & $\begin{array}{c}0.826^{\cdots} \cdot \\
(0.18)\end{array}$ & $\begin{array}{l}-0.246 \\
(0.19)\end{array}$ & $\begin{array}{c}0.819 \cdots \\
(0.18)\end{array}$ & $\begin{array}{c}-0.026 \\
(0.18)\end{array}$ & $\begin{array}{c}0.422 . \\
(0.19)\end{array}$ \\
\hline Computer software & $\begin{array}{l}-0.010 \\
(0.14)\end{array}$ & $\begin{array}{c}0.490^{\circ} \cdots \\
(0.11)\end{array}$ & $\begin{array}{l}0.110 \\
(0.13)\end{array}$ & $\begin{array}{l}0.165 \\
(0.12)\end{array}$ & $\begin{array}{l}-0.051 \\
(0.14)\end{array}$ & $\begin{array}{c}0.448^{\cdots} \\
(0.11)\end{array}$ & $\begin{array}{l}-0.046 \\
(0.14)\end{array}$ & $\begin{array}{c}0.456^{\cdots} \\
(0.11)\end{array}$ & $\begin{array}{l}0.148 \\
(0.13)\end{array}$ & $\begin{array}{l}0.207^{*} \\
(0.12)\end{array}$ \\
\hline Electronic equipments & $\begin{array}{l}-0.286 \\
(0.18)\end{array}$ & $\begin{array}{c}0.882^{\cdots} \\
(0.17)\end{array}$ & $\begin{array}{l}-0.111 \\
(0.17)\end{array}$ & $\begin{array}{c}0.582 \cdots \\
(0.17)\end{array}$ & $\begin{array}{l}-0.314^{*} \\
(0.18)\end{array}$ & $\begin{array}{c}0.927^{\cdots} \\
(0.16)\end{array}$ & $\begin{array}{c}-0.300^{\circ} \\
(0.18)\end{array}$ & $\begin{array}{c}0.912 \cdots \\
(0.16)\end{array}$ & $\begin{array}{l}-0.106 \\
(0.17)\end{array}$ & $\begin{array}{c}0.577^{\cdots} \\
(0.17)\end{array}$ \\
\hline Total Ph.D. & $\begin{array}{l}0.039 \\
(0.03)\end{array}$ & $\begin{array}{c}0.219 \cdots \\
(0.03)\end{array}$ & & & & & & & $\begin{array}{l}0.054^{*} \\
(0.03)\end{array}$ & $\begin{array}{c}0.172^{\cdots} \cdot \\
(0.03)\end{array}$ \\
\hline htdummy & & $\begin{array}{c}0.326^{\cdots} \cdot \\
(0.10)\end{array}$ & & $\begin{array}{l}0.241 . " \\
(0.11)\end{array}$ & & $\begin{array}{c}0.373^{\cdots} \\
(0.10)\end{array}$ & & $\begin{array}{c}0.372 \cdots \\
(0.10)\end{array}$ & & $\begin{array}{l}0.200^{\circ} \\
(0.11)\end{array}$ \\
\hline employees & & $\begin{array}{c}-0.173 \cdots \\
(0.04)\end{array}$ & & $\begin{array}{c}-0.137^{\cdots} \\
(0.04)\end{array}$ & & $\begin{array}{c}-0.168 \cdots \\
(0.04)\end{array}$ & & $\begin{array}{c}-0.189^{\cdots} \\
(0.04)\end{array}$ & & $\begin{array}{c}-0.117^{\cdots} \\
(0.04)\end{array}$ \\
\hline$R \& D$ Intensity & & & $\begin{array}{l}-0.024 \\
(0.02)\end{array}$ & $\begin{array}{c}0.092^{\cdots} \\
(0.01)\end{array}$ & & & & & $\begin{array}{l}-0.025 \\
(0.02)\end{array}$ & $\begin{array}{c}0.085 \cdots \\
(0.01)\end{array}$ \\
\hline Sales Growth & & & & & $\begin{array}{l}0.026 \\
(0.07)\end{array}$ & $\begin{array}{l}-0.088 \\
(0.06)\end{array}$ & & & $\begin{array}{l}0.031 \\
(0.07)\end{array}$ & $\begin{array}{c}-0.049 \\
(0.07)\end{array}$ \\
\hline VC Rounds & & & & & & & $\begin{array}{l}-0.022 \\
(0.02)\end{array}$ & $\begin{array}{l}0.030^{\circ} \\
(0.02)\end{array}$ & $\begin{array}{l}-0.021 \\
(0.02)\end{array}$ & $\begin{array}{l}0.018 \\
(0.02)\end{array}$ \\
\hline Rho & \multicolumn{2}{|c|}{$-0.867^{\cdots *}$} & \multicolumn{2}{|c|}{$-0.865^{\cdots}$} & \multicolumn{2}{|c|}{$-0.887^{\cdots \cdot}$} & \multicolumn{2}{|c|}{$-0.883^{\cdots}$} & \multicolumn{2}{|c|}{$-0.855^{\cdots}$} \\
\hline N & 1.142 & 2.217 & 1.142 & 2.217 & 1.142 & 2.217 & 1.142 & 2.217 & 1.142 & 2.217 \\
\hline Log-Likelihood & \multicolumn{2}{|c|}{$-1,653$} & \multicolumn{2}{|c|}{$-1,630$} & \multicolumn{2}{|c|}{-1.686} & \multicolumn{2}{|c|}{$-1,685$} & \multicolumn{2}{|c|}{$-1,606$} \\
\hline
\end{tabular}

Standard errors in parentheses. ${ }^{\prime} p<0.01 . " p<0.05 . " p<0.1$. Year dummies included in all models. 
TABLE 4: FOUNDER-CEO RETENTION (Probit)

\begin{tabular}{|c|c|c|c|c|c|}
\hline & (1) & (2) & (3) & (4) & (5) \\
\hline Venture-backed & $\begin{array}{l}-0.052^{*} \\
(0.03)\end{array}$ & $\begin{array}{l}-0.039 \\
(0.03)\end{array}$ & $\begin{array}{c}-0.049^{\circ} \\
(0.03)\end{array}$ & $\begin{array}{l}0.049 \\
(0.03)\end{array}$ & $\begin{array}{l}0.061^{\circ} \\
(0.03)\end{array}$ \\
\hline NASDAQ & $\begin{array}{l}0.036 \\
(0.03)\end{array}$ & $\begin{array}{l}0.043 \\
(0.03)\end{array}$ & $\begin{array}{l}0.042 \\
(0.03)\end{array}$ & $\begin{array}{l}0.045 \\
(0.03)\end{array}$ & $\begin{array}{l}0.040 \\
(0.03)\end{array}$ \\
\hline Underwriter Prestige & $\begin{array}{l}0.004 \\
(0.01)\end{array}$ & $\begin{array}{l}0.007 \\
(0.01)\end{array}$ & $\begin{array}{l}0.005 \\
(0.01)\end{array}$ & $\begin{array}{l}0.008 \\
(0.01)\end{array}$ & $\begin{array}{l}0.008 \\
(0.01)\end{array}$ \\
\hline Profitable (a) IPO & $\begin{array}{l}-0.005 \\
(0.03)\end{array}$ & $\begin{array}{l}-0.019 \\
(0.03)\end{array}$ & $\begin{array}{l}-0.016 \\
(0.03)\end{array}$ & $\begin{array}{l}-0.024 \\
(0.03)\end{array}$ & $\begin{array}{l}-0.022 \\
(0.03)\end{array}$ \\
\hline Sales (In) & $\begin{array}{l}0.001 \\
(0.01)\end{array}$ & $\begin{array}{c}-0.004 \\
(0.01)\end{array}$ & $\begin{array}{c}-0.002 \\
(0.01)\end{array}$ & $\begin{array}{l}-0.001 \\
(0.01)\end{array}$ & $\begin{array}{c}-0.007 \\
(0.01)\end{array}$ \\
\hline Insider Precentage & $\begin{array}{c}0.003^{\cdots} \\
(0.00)\end{array}$ & $\begin{array}{c}0.003^{\cdots} \\
(0.00)\end{array}$ & $\begin{array}{c}0.003^{\cdots} \\
(0.00)\end{array}$ & $\begin{array}{c}0.002 \cdots \\
(0.00)\end{array}$ & $\begin{array}{c}0.002^{\cdots} \\
(0.00)\end{array}$ \\
\hline Age (In) & $\begin{array}{c}0.250^{\cdots} \\
(0.05)\end{array}$ & $\begin{array}{c}0.266 \cdots \\
(0.05)\end{array}$ & $\begin{array}{c}0.262 \cdots \\
(0.05)\end{array}$ & $\begin{array}{c}0.274 \cdots \\
(0.05)\end{array}$ & $\begin{array}{c}0.279 \cdots \\
(0.05)\end{array}$ \\
\hline Age (In, squared) & $\begin{array}{c}-0.074 \cdots \\
(0.01)\end{array}$ & $\begin{array}{c}-0.078 * * \\
(0.01)\end{array}$ & $\begin{array}{c}-0.076^{\cdots} \cdot \cdots \\
(0.01)\end{array}$ & $\begin{array}{c}-0.080^{\cdots} \\
(0.01)\end{array}$ & $\begin{array}{c}-0.080^{* * *} \\
(0.01)\end{array}$ \\
\hline West Coast & $\begin{array}{l}0.028 \\
(0.03)\end{array}$ & $\begin{array}{l}0.043 \\
(0.03)\end{array}$ & $\begin{array}{l}0.035 \\
(0.03)\end{array}$ & $\begin{array}{l}0.047^{*} \\
(0.03)\end{array}$ & $\begin{array}{l}0.051^{*} \\
(0.03)\end{array}$ \\
\hline North East & $\begin{array}{l}0.028 \\
(0.03)\end{array}$ & $\begin{array}{l}0.032 \\
(0.03)\end{array}$ & $\begin{array}{l}0.030 \\
(0.03)\end{array}$ & $\begin{array}{l}0.035 \\
(0.03)\end{array}$ & $\begin{array}{l}0.038 \\
(0.03)\end{array}$ \\
\hline Medical equipment & $\begin{array}{r}-0.085^{\circ} \\
(0.05)\end{array}$ & $\begin{array}{l}-0.035 \\
(0.05)\end{array}$ & $\begin{array}{l}-0.074 \\
(0.05)\end{array}$ & $\begin{array}{l}-0.056 \\
(0.05)\end{array}$ & $\begin{array}{l}-0.023 \\
(0.05)\end{array}$ \\
\hline Pharmaceutical products & $\begin{array}{r}-0.093^{\circ} \\
(0.05)\end{array}$ & $\begin{array}{l}0.012 \\
(0.05)\end{array}$ & $\begin{array}{l}-0.032 \\
(0.05)\end{array}$ & $\begin{array}{l}-0.014 \\
(0.05)\end{array}$ & $\begin{array}{l}-0.041 \\
(0.05)\end{array}$ \\
\hline Business service & $\begin{array}{l}-0.005 \\
(0.04)\end{array}$ & $\begin{array}{l}0.025 \\
(0.04)\end{array}$ & $\begin{array}{l}0.012 \\
(0.04)\end{array}$ & $\begin{array}{l}0.015 \\
(0.04)\end{array}$ & $\begin{array}{l}0.010 \\
(0.04)\end{array}$ \\
\hline Computer hardware & $\begin{array}{l}-0.014 \\
(0.06)\end{array}$ & $\begin{array}{l}0.043 \\
(0.06)\end{array}$ & $\begin{array}{l}-0.008 \\
(0.06)\end{array}$ & $\begin{array}{l}-0.008 \\
(0.06)\end{array}$ & $\begin{array}{l}0.044 \\
(0.06)\end{array}$ \\
\hline Computer software & $\begin{array}{l}-0.001 \\
(0.03)\end{array}$ & $\begin{array}{l}0.037 \\
(0.03)\end{array}$ & $\begin{array}{l}0.001 \\
(0.03)\end{array}$ & $\begin{array}{l}0.004 \\
(0.03)\end{array}$ & $\begin{array}{l}0.049 \\
(0.03)\end{array}$ \\
\hline Electronic equipment & $\begin{array}{l}-0.030 \\
(0.05)\end{array}$ & $\begin{array}{l}0.027 \\
(0.05)\end{array}$ & $\begin{array}{l}-0.017 \\
(0.05)\end{array}$ & $\begin{array}{l}-0.006 \\
(0.05)\end{array}$ & $\begin{array}{l}0.028 \\
(0.05)\end{array}$ \\
\hline Total Ph.D. & $\begin{array}{c}0.023^{* *} \\
(0.01)\end{array}$ & & & & $\begin{array}{c}0.031 \cdots \\
(0.01)\end{array}$ \\
\hline R\&D Intensity & & $\begin{array}{c}-0.008^{*} \\
(0.00)\end{array}$ & & & $\begin{array}{c}=0.009^{\cdots \cdot} \\
(0.00)\end{array}$ \\
\hline Sales Growth & & & $\begin{array}{l}0.007 \\
(0.02)\end{array}$ & & $\begin{array}{l}0.006 \\
(0.02)\end{array}$ \\
\hline VC Rounds & & & & $\begin{array}{c}-0.028^{\cdots} \\
(0.01)\end{array}$ & $\begin{array}{c}-0.029 \cdots \\
(0.01)\end{array}$ \\
\hline $\mathrm{N}$ & 2.217 & 2.217 & 2,217 & 2.217 & 2.217 \\
\hline Log-Likelihood & $-1,461$ & $-1,462$ & $-1,464$ & $-1,452$ & $-1,443$ \\
\hline
\end{tabular}

Standard errors in parentheses ${ }^{\prime \prime} p<0.01 .{ }^{\prime} p<0.05 .{ }^{~} p<0.1$ Year dummies included in all 
TABLE 5: FOUNDER-CFO RETENTION (Probit)

\begin{tabular}{|c|c|c|c|c|c|}
\hline & (1) & (2) & (3) & (4) & (5) \\
\hline Venture-backed & $\begin{array}{l}-0.021 \\
(0.02)\end{array}$ & $\begin{array}{l}-0.016 \\
(0.02)\end{array}$ & $\begin{array}{l}-0.020 \\
(0.02)\end{array}$ & $\begin{array}{l}0.018 \\
(0.02)\end{array}$ & $\begin{array}{l}0.023 \\
(0.02)\end{array}$ \\
\hline NASDAQ & $\begin{array}{l}-0.022 \\
(0.02)\end{array}$ & $\begin{array}{l}-0.018 \\
(0.02)\end{array}$ & $\begin{array}{l}-0.019 \\
(0.02)\end{array}$ & $\begin{array}{l}-0.018 \\
(0.02)\end{array}$ & $\begin{array}{l}-0.020 \\
(0.02)\end{array}$ \\
\hline Underwriter Prestige & $\begin{array}{c}-0.007^{* *} \\
(0.00)\end{array}$ & $\begin{array}{c}-0.006^{*} \\
(0.00)\end{array}$ & $\begin{array}{c}-0.006^{\circ} \\
(0.00)\end{array}$ & $\begin{array}{l}-0.005 \\
(0.00)\end{array}$ & $\begin{array}{l}-0.005 \\
(0.00)\end{array}$ \\
\hline Profitable () IPO & $\begin{array}{l}0.000 \\
(0.02)\end{array}$ & $\begin{array}{l}-0.005 \\
(0.02)\end{array}$ & $\begin{array}{l}-0.001 \\
(0.02)\end{array}$ & $\begin{array}{l}-0.007 \\
(0.02)\end{array}$ & $\begin{array}{l}-0.004 \\
(0.02)\end{array}$ \\
\hline Sales (In) & $\begin{array}{l}-0.002 \\
(0.00)\end{array}$ & $\begin{array}{l}-0.004 \\
(0.00)\end{array}$ & $\begin{array}{l}-0.001 \\
(0.00)\end{array}$ & $\begin{array}{l}-0.003 \\
(0.00)\end{array}$ & $\begin{array}{l}-0.003 \\
(0.00)\end{array}$ \\
\hline Insider Precentage & $\begin{array}{l}0.000^{*} \\
(0.00)\end{array}$ & $\begin{array}{c}0.000^{*} \\
(0.00)\end{array}$ & $\begin{array}{l}0.000^{*} \\
(0.00)\end{array}$ & $\begin{array}{l}0.000 \\
(0.00)\end{array}$ & $\begin{array}{l}0.000 \\
(0.00)\end{array}$ \\
\hline Age $(\ln )$ & $\begin{array}{l}-0.015 \\
(0.02)\end{array}$ & $\begin{array}{l}-0.009 \\
(0.02)\end{array}$ & $\begin{array}{l}-0.015 \\
(0.03)\end{array}$ & $\begin{array}{l}-0.008 \\
(0.02)\end{array}$ & $\begin{array}{l}-0.011 \\
(0.03)\end{array}$ \\
\hline Age (In, squared) & $\begin{array}{c}-0.004 \\
(0.01)\end{array}$ & $\begin{array}{c}-0.006 \\
(0.01)\end{array}$ & $\begin{array}{c}-0.005 \\
(0.01)\end{array}$ & $\begin{array}{l}-0.006 \\
(0.01)\end{array}$ & $\begin{array}{l}-0.005 \\
(0.01)\end{array}$ \\
\hline West Coast & $\begin{array}{l}-0.009 \\
(0.02)\end{array}$ & $\begin{array}{l}-0.003 \\
(0.02)\end{array}$ & $\begin{array}{l}-0.007 \\
(0.02)\end{array}$ & $\begin{array}{l}-0.001 \\
(0.02)\end{array}$ & $\begin{array}{l}-0.001 \\
(0.02)\end{array}$ \\
\hline North East & $\begin{array}{c}0.051^{\cdots} \\
(0.02)\end{array}$ & $\begin{array}{c}0.054 \cdots \\
(0.02)\end{array}$ & $\begin{array}{c}0.051 \cdots \\
(0.02)\end{array}$ & $\begin{array}{c}0.053^{\cdots} \\
(0.02)\end{array}$ & $\begin{array}{c}0.054^{\cdots} \\
(0.02)\end{array}$ \\
\hline Medical equipment & $\begin{array}{c}-0.007 \\
(0.03)\end{array}$ & $\begin{array}{l}0.013 \\
(0.03)\end{array}$ & $\begin{array}{l}-0.002 \\
(0.03)\end{array}$ & $\begin{array}{l}0.005 \\
(0.03)\end{array}$ & $\begin{array}{l}0.016 \\
(0.03)\end{array}$ \\
\hline Pharmaceutical products & $\begin{array}{l}-0.022 \\
(0.03)\end{array}$ & $\begin{array}{l}0.019 \\
(0.03)\end{array}$ & $\begin{array}{l}0.001 \\
(0.03)\end{array}$ & $\begin{array}{l}0.010 \\
(0.03)\end{array}$ & $\begin{array}{l}-0.003 \\
(0.03)\end{array}$ \\
\hline Business service & $\begin{array}{l}-0.008 \\
(0.02)\end{array}$ & $\begin{array}{l}0.004 \\
(0.02)\end{array}$ & $\begin{array}{l}-0.001 \\
(0.02)\end{array}$ & $\begin{array}{l}0.000 \\
(0.02)\end{array}$ & $\begin{array}{l}-0.003 \\
(0.02)\end{array}$ \\
\hline Computer hardware & $\begin{array}{l}-0.029 \\
(0.03)\end{array}$ & $\begin{array}{l}-0.011 \\
(0.04)\end{array}$ & $\begin{array}{c}-0.027 \\
(0.03)\end{array}$ & $\begin{array}{l}-0.027 \\
(0.03)\end{array}$ & $\begin{array}{l}-0.012 \\
(0.03)\end{array}$ \\
\hline Computer software & $\begin{array}{l}0.001 \\
(0.02)\end{array}$ & $\begin{array}{l}0.013 \\
(0.02)\end{array}$ & $\begin{array}{l}-0.000 \\
(0.02)\end{array}$ & $\begin{array}{l}0.002 \\
(0.02)\end{array}$ & $\begin{array}{l}0.017 \\
(0.02)\end{array}$ \\
\hline Electronic equipment & $\begin{array}{l}-0.030 \\
(0.03)\end{array}$ & $\begin{array}{l}-0.011 \\
(0.03)\end{array}$ & $\begin{array}{l}-0.025 \\
(0.03)\end{array}$ & $\begin{array}{l}-0.020 \\
(0.03)\end{array}$ & $\begin{array}{l}-0.011 \\
(0.03)\end{array}$ \\
\hline Total Ph.D. & $\begin{array}{c}0.010^{*} \\
(0.00)\end{array}$ & & & & $\begin{array}{l}0.012^{* *} \\
(0.00)\end{array}$ \\
\hline R\&D Intensity & & $\begin{array}{c}-0.003 \\
(0.00)\end{array}$ & & & $\begin{array}{c}-0.003^{\circ} \\
(0.00)\end{array}$ \\
\hline Sales Growth & & & $\begin{array}{c}-0.004 \\
(0.01)\end{array}$ & & $\begin{array}{c}-0.004 \\
(0.01)\end{array}$ \\
\hline VC Rounds & & & & $\begin{array}{c}-0.012 \cdots \\
(0.00)\end{array}$ & $\begin{array}{c}-0.012 \cdots \\
(0.00)\end{array}$ \\
\hline $\mathrm{N}$ & 2,217 & 2,217 & 2,217 & 2.217 & 2.217 \\
\hline Log-Likelihood & -720 & -721 & -722 & -717 & -713 \\
\hline
\end{tabular}

